isolated teeth. In the early Miocene a very interesting form occurs, named Amphicyon, characterised by the greater development of the tubercular molars, which are not only larger relatively than in modern dogs, but the one missing in them is present, making the typical number complete. In addition to this generalisation in the dental characters, they possessed five toes on each foot, whereas the modern dogs have lost the hallux. They were large heavy-limbed animals, and have been supposed to present affinities to the bears, which, however, they only do inasmuch as they are more generalised carnivora than are the typical dogs. Remains have been found in various Miocene deposits in France, Germany, Italy, and some assigned to the same genus in North America. It is doubtful if the cynoid or dog-like type of carnivore was distinctly recognisable in the Eocene period, for the Canis parisiensis of the Paris gypsums was founded on a single tooth.

From the dogs, which hold a very central position in the order, the other existing members deviate in two different directions, one extending through the weasels and martens to the otters and bears, which make the nearest approach to the seals, and the other through the civets and hyænas to the cats, the most highly specialised and characteristic carnivores. The true bears are especially distinguished by the great development of the tubercular and the suppression of the sectorial portion of the molar series. The peculiar dentition of a bear is, for a carnivorous animal, highly specialised, and, as might be expected, appears to be a comparative recent introduction upon the earth, not exterding beyond the Pliocene epoch, though several transitional forms occur, as Arctotherinm bonariensis of South America, and Hycenarctos sivalensis of the Siwalik Mountain, and $H$. insignis of the Pliocene of Montpellier. Otters have been traced back to the Pliocene in France, and an allied form Potamotherium, to the Miocene. Enhydriodon is a large otter-Jike animal from the Siwalik Hills, with very broad and tuberculated molars. The evidence as to the ancient history of the Mastelide is not very satisfactory, as isolated teeth, by which many of the fossil forms are known, are not sufficient indications as to their general characters.

True Viverrida are met with in the European Miocenes, one genus, 1ctitherizm, forming a transition to the Hyænas. The latter first appeared in the Upper Miocenes of Europe in forms intermediate between the extremes of existing species, and continued abundant until the close of the Pleistocene, but are now restricted to Africa and Asia. The species so common in the British caves appears to have been identical with the Spotted Hyæna (H. croceta) of Africa, and the Striped Hyæna (H. striata), has been found fossil in France. The genus has not been met with in America.

The Felidce present the most complete adaptive modification of the carnivorous type for a predatory existence. The jaws are short and wide, the incisors very small, the canines powerful, and the molar series shortened, and its sectorial element developed almost to the complete suppression of the tubercular portion. The limbs and claws have undergone corresponding specialisations. The family has now a very wide distribution, and has existed both in Europe and America since the Miocene period. It acquired one most remarkable modification in the animals known as Machorodus and Drepanodon, in which the upper canine was developed to an extraordinary degree, projecting down from out o the mouth like huge sabre-like tusks. In other respects the animal was constructed much on the ordinary feline type. They were widely distributed both in time and space, being found in North and South America, in Europe (including Britain), and in India, and ranging from Miocene to Pleistocene epochs, when they became quite extinct.

(To be continued.)

\section{UNIVERSITY COLLEGE, BRISTOL}

THIS college is now being incorporated under the Board of Trade as a company limited by guarantee, under the Companies' Acts, 1862 and 1867 . The Board of Governors is the supreme governing body, and comprises all con ributors above $5 l$., and a large number of honorary members, with various qualifications, resident in various parts of the West of England. The Council is the managing body, consisting of sixteen, one-half of whom are elected by the governors (in the first instance by the contributors of money, about 20,000 l. having been already promised in Bristol alone), and the other half are nominated by the Vice-Chancellors of the Universities of Oxford, Cambridge, and London, by the two contributing Oxford Colleges, by the Lord-President of the Privy Council, by the faculty of the old-established Bristo Medical School, and by the Principal and professors of the College.

The Council comprises the following names :-

Elected by the Contributors.-W. P. Baker, merchant F. N. Budd, barrister; Rev. J. W. Caldicott, Head Master, Grammar School; Lewis Fry, School Board Chairman, solicitor; Rev. F. W. Gotch, Principal, Baptist College ; Rev. I. Percival, Head Master, Clifton College; G. F. Schacht, phamacist; „W. Smith, merchant.

Prof. B. Jowett, nominated by Vice-Chancellor of Oxford; Prof. Stuart, nominated by Vice-Chancellor of Cambridge; W. L. Carpenter, nominated by ViceChancellor of London; Prof. Henry Smith, nominated by Balliol College; Rev. H. B. George, nominated by New College; R. W. Coe, nominated by Bristol Medical School.

At their preliminary meeting, held recently, the Council decided to commence operations in October next, and to appoint at first a Professor of Chemistry and a Professor of Modern History and Literature.

A piece of land has already been secured, but, for the first session or more, the lectures will be given in temporary premises. In all except the strictly medical classes of the medical school (which is being affiliated with the New College), the instruction will be open to young people of both sexes. Other courses of occasional lectures will be organised during the session.

In addition to the aid afforded by Balliol and New Colleges, Oxford, the Worshipful Company of Clothworkers in London have spontaneously offered a very handsome subvention to the College, with the view of establishing a department of Textile Industries for the improvement of the technical education of the West of England cloth manufacturing districts, as Stroud, Trowbridge, \&c. It is believed that special attention will be given to the chemistry of dyeing and wool scouring, as well as to the mechanical part of the manufacture. The details of the arrangements are under the consideration of the Council and of a committee of cloth manufacturers and others, by whom very great interest is felt in the proposed scheme.

The registered temporary office of the College is Shannon Court, Bristol, and letters sent to the Secretary of University College, Bristol, at that address, will be attended to.

The Council are seeking for a permanent secretary, and offer a salary of $200 l$. per year. They hope to obtain the services of a gentleman who will throw himself with zeal and interest into the establishment of the College.

\section{THE USE OF YELLOW GLASS FOR ZOOLO GICAL COLLECTIONS}

$A T$ a recent meeting of the $e_{j}$ Entomological Society of Belgium, M. Capronnier read a paper giving an account of some experiments which he had made bearing on the question as to how public collections of insects 
may best be exhibited so as to satisfy all the purposes for which they are intended. M. Felix Platcau, at a former meeting, proposed to substitute ycllow for colourless glass in lighting rooms containing entomological collections. In the discussion which followed it was sugcrested that experiments should be made by submitting insects to the influence of glasses of various colours. M. Capronnicr was entrusted with carrying out these cxperiments, and the paper referred to contains his report.

Everyone knows that among the I.epicloptera it is the grecn ard carmine colours which are most rapidly destroyed by dayliglit. M. Capronnier wished to obtain insects of the ycar's hatching, but could only obtain sufficient quantities of Euchelia Facobce, I. The inferior wings of this insect are of a decp carmine, uniform in tone, an important point in the experiments.

The principal colours of the solar spcctrum are the yellow, the red, the blue. M. Capronnier rejected the red as giving a tint too dark, and added the mixed colours, violet and green. He had thus four tints chosen with the same degree of tone, and of a moderate shadeyellow, violet, green, and bluc, besides a colourless glass. He made five small square boxes of 08 centimetres square and one centimetre in depth; the whole surface was covered with one of the above-mentioned glasses.

Fach wing was fixed in the middle of the box and floated in a bath of very bright light, but r rotected from the rays of the sun. Each of the wings was partly covered by a band of black paper, and their position was so arranged as to leave exposed successively each of the parts during a period of fifteen, thirty, and ninety days. The following are the results:-

Colourless glass.-After fifteen days of exposure the carmine tint was visibly attacked. After thirty days the alteration was more sensible, and after ninety days the work of destruction had rapidly advanced, and the carminc had passed into a jellowish tint.

In!we--With this tint the same allerations took place as in thic case of colourless grass.

Green.-This colour preserved the carmine during the first fifteen days; a change was indicated on the thirticth day, and on the nintieth the alteration was marked.

Yollow:-During the nincty days the yellow alone left the carmine colour almost intact. M. Capronnier says almost, for a slighit aliciation in the tint could be notlced at the end of the nitiety days. This last observation proves that there is no absolute preservative, and that collections must be ke $\mathrm{t}$ in darkness, under penalty of secing them seriously changed at the end of a given time.

Nevertheless, it is evident from the above that the ycllow is the best prescrvative against alterations in the colours of insccts. M.T. Capronnicr consequeritly concludes that a yellowish colour should be preferred and combincd in cvery arranrement of an cntomological room. Moreover the cloths that cover the show-cases oushit to be yellow rather than green, and wiat is important and indispensable, the window-blinds oungt to be absolutely ycllow.

\section{RADIOMETERS ${ }^{1}$}

$D^{u}$

URING the discussion which followed the reading of Prof. Reynolds's and Dr. Scliuster's papers at the last mecting of the Royal Society I mentioned an experiment bearing on the observations of Dr. Schuster. I have since tried this in a form; and as the results are very decided and appear calculated to throw light on many disputed points in the theory of these obscure actions, I venture to bring a description of the experiment, and to show the apparatus at work, before the Society.

I made use of a radiometer described in a paper comI "On the Movement of the Glass Case of a Radiometer." By William Crookes, F.K.S., \&c. Read at the Royal Society. municated to the Socicty in January last. I quote the description from paragraph 184 . " $\Lambda$ large radiometer in a 4-inch bulb was made with ten arms, eight of them being of brass, and the other two being a long watch-spring magnet. The discs werc of pith, blackened on one side. The powcr of the earth on the magnet is too great to allow the arms to be set in rotation unless a candle is brought near, but once started it will continue to revolve with the light some distance off."

This radiometer was floated in a vessel of water and four candles were placed round it, so as to set the arms in rotation. A mark was put on the glass envelope so as to enable a slight movement of rotation to be seen. The envelope turned very slowly a few degrees in one direction, then stopped and turned a few degrees the opposite way ; finally it took up a uniform but excessively slow movement in the direction of the arms, but so slow that more than an hour would be occupied in one revolution.

$\Lambda$ powerful magnet was now brought near the moving arms. They immediately stopped, and at the same time the glass envclope commenced to revolve in the opposite dircction to that in which the arms had been revolving. The movement kept up as long as the candles were burning, and the specd was onc revolution in two minutes.

The magnet was removed, the arms obeycd the force of radiation from the candles, and revolved rapidly, whilst the glass envelope quickly came to rest and then rotated very slowly the same way as the arms went.

The candles were blown out ; and as soon as the whole instrument had come to rest, a bar-magnet was moved altcrnately from one side to the other of the radiometer, so as to cause the vanes to rotate as if they had been under the influence of a candle. The grlass cnvelope thoved with some rapidity (about one revolution in three minutes) in the direction the arms were moving. On reversing the dircction of movement of the arms the glass envelope changed direction also.

These experiments show that the internal friction, cither of the stecl point on the glass socket, of the vanes against the residual air, or of both these causes combined, is considerable. Moving the vancs rcund by the exterior magnet carries the whole envelope round in opposition to the friction of the water against the glass.

As there is indidi discussion at present respecting the catise of these movements, and as some misunderstanding seems to prevail as to my own views on the theory of the repulsion resulting from radiation, I wish to take this opportunity of removing the impression that I hold opinions which are in antagonism to some strongly urged explanations of these actions. I have on five or six occasions specially stated that I wish to keep free from theorics. During my four ycars' work on this subjcct I have accuimulated a large fund of experimental observations, and these: often cnable me to see difficultics which could not be cxpected to occur to an investigator who has had but a limited experience with the working of one or two instruments.

COMPLESSEJ AIR LOCOMOTIVE USED IN THE : $\%$ COOTIRL TUNNEL WORKS'

THE boring of a tunncl of any importance presents difficulties of various kinds, among which may bc mentioncd the clearing away of the rubbish arising from the cxcavation of the gallery, whenever that reaches any considerable length, and the work is carried on with activity. Such were the conditions under which the boring of the Mont Cenis tunnel was carried on, and M. Fabre, the able contractor, has met with similar difficulties in the boring of the St. Gothard tunnel, now being carried out.

- From an article in La Nalwre, by M. C. M. Gariel. 